\title{
NOTE
}

\section{Vegetative propagation of the red alga Rhodochorton purpureum by means of fragments that escape digestion by herbivores}

\author{
A. M. Breeman \& B. W. Hoeksema \\ Department of Marine Biology, University of Groningen, Biological Centre, PO Box 14, 9750 AA Haren (Gn), The Netherlands
}

\begin{abstract}
Intertidal populations of the filamentous red alga Rhodochorton purpureum (Lightf.) Rosenv. (Nemaliales, Acrochaetiaceae) in the Northern Netherlands grow as dense velvety turfs in the understory of large fucalean algae. The small and rather constant size of the turf ( 1 to $1.5 \mathrm{~mm}$ ) and the high percentage of 'decapitated' filaments suggest that the turf is continually 'shorn' by herbivores. Two grazing invertebrates were found on the turf: the gastropod Littorina littorea (L.) and the amphipod Gammarus salinus Spooner Differences between the 2 grazers in the size of ingested $R$. purpureum fragments and in the proportion of ingested fragments with intact apices were attributed to differences in their feeding mechanisms. Both species egested live $R$. purpureum fragments in their faecal pellets. These fragments had the capacity to regenerate into new filaments when cultured in the laboratory. In the field small tufts of $R$. purpureum filaments were found on bare substratum, originating from fragments contained in sticky, detritus-rich envelopes, probably faecal pellets. Experiments in unialgal cultures showed that the regenerative capacity of fragments is very high, as it proceeds over a broad range of temperature and light conditions, even in total darkness. We conclude that the capacity of $R$. purpureum fragments to escape digestion by herbivores probably plays an important role in vegetative propagation of the species.
\end{abstract}

Recent accounts on seaweed-herbivore interactions have focused on defensive and escape mechanisms of the algae as adaptive strategies to survive herbivory (Lubchenco \& Gaines 1981, Hawkins \& Hartnoll 1983, Vadas 1985). These accounts have considered herbivory merely as a source of algal mortality, and have disregarded the possibility that ingested algal material may escape digestion by the herbivore and thus serve as a propagule for dispersal. The adaptive importance of the ability to escape digestion by herbivores was pointed out by Santelices et al. (1983) and Santelices \& Correa (1985) who found that opportunistic species escaped digestion more often than late successional forms thus giving an extra advantage in the colonisation of heavily grazed areas.
This paper reports on the capacity of the red alga Rhodochorton purpureum (Lightf.) Rosenv. (Nemaliales, Acrochaetiaceae) to escape digestion by 2 marine invertebrates: the gastropod Littorina littorea (L.) and the amphipod Gammarus salinus Spooner. In $R$. purpureum dispersal is probably largely dependent on fragmentation. Tetraspores are the only type of spores in the life history (West 1969, Stegenga 1978, Ohta \& Kurogi 1979), and although tetraspores have frequently been observed in field populations (West 1972 , Breeman et al. 1984), gametophytes have been found in nature only once (Breeman et al. 1984), suggesting that the sexual cycle is completed in the field only rarely.

Several authors have suggested that fragmentation resulting from physical or chemical damage, such as wave action or insolation, is the principal mode of propagation in Rhodochorton purpureum (Knaggs 1966, 1967, Pearlmutter \& Vadas 1978). This view was supported by the observation that the regenerative capacity of fragments is high. Regenerating fragments first form one or more adhesive rhizoids and subsequently new filamental shoots (Pearlmutter \& Vadas 1978).

Characteristically, intertidal Rhodochorton purpureum populations grow as dense velvety turfs in the understory of large fucalean algae. We studied a highto midlitoral $R$. purpureum population in the Northern Netherlands (Breeman et al. 1984) and found that the turf was rather constant in height, reaching a size of only 1 to $1.5 \mathrm{~mm}$ (Fig. 1). This is in striking contrast to the size of culture-grown plants which may be several centimeters long (Breeman pers. obs.). The field population also had a high proportion (ca $25 \%$ ) of filaments with 'decapitated' apices (Fig. 1), suggesting that the turf is continually 'shorn' to a uniform size by grazers. Knaggs (1966) reported an even higher percentage 


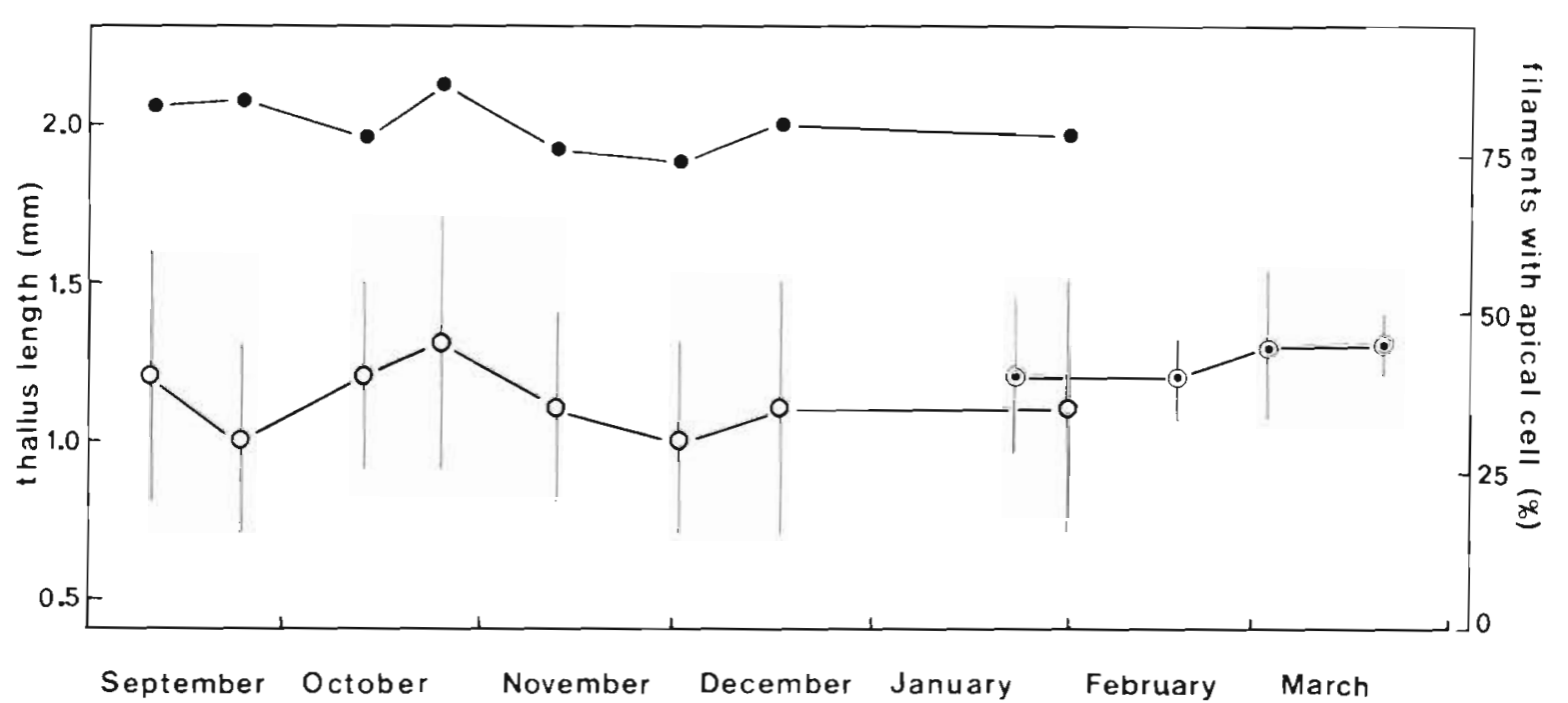

Fig. 1. Rhodochorton purpureum. Size of turf $\left(-\_\right.$and $\left.\odot-\odot\right)$ and number of filaments with intact apices $(\bullet-\bullet)(\mathrm{n} \approx 500)$ in field samples collected in autumn and winter of 1980/1981 $(-\infty)(\mathrm{n}=20)$ and in the early spring of $1982(\odot-\odot)(\mathrm{n}=50)$; vertical bars: SD

$(64 \%)$ of 'decapitated' filaments for a supralitoral $R$. purpureum population in Scotland, where the plants were only ca $0.4 \mathrm{~mm}$ high. He attributed this to physical damage due to insolation, but we suggest that heavy grazing in this typically Littorina dominated shore zone may have been responsible.

In the Rhodochorton purpureum population in the Northern Netherlands (Breeman et al. 1984) we found 2 potential grazers on the turf: the snail Littorina littorea and the amphipod Gammarus salinus. In the guts of both animals $R$. purpureum fragments were found which seemed to be still alive. In the stomach of L. littorea $40 \%$ of these fragments lacked intact apices (Fig. 2A) and fragments with intact apices were significantly longer than those without intact apices (MannWhitney U-test; $\mathrm{p}<0.0005$ ). In contrast, in the guts of G. salinus up to $70 \%$ of the fragments lacked intact apices, but there was no significant difference in the size of fragments with or without an intact apex (Mann-Whitney U-test; $p>0.05$; Fig. 2B). We suggest that these differences in the size and condition of the ingested fragments reflect differences between the 2 grazers in the mode of action of their feeding apparatus.

The taenioglossan radula ('rake') of Littorina littorea performs an inward movement in raking and cutting the algal filaments while the teeth converge toward the central axis of the radula during retraction (Steneck \& Watling 1982). Grazing traces show that more than one tooth passes the same spot during one bite (Jüch \& Boekschoten 1980). In consequence, a filament which has had its apical portion cut off by the first tooth will have another, smaller, portion cut off by the next tooth.
In contrast, Gammarus salinus manipulates its food with 2 pairs of gnatopods and bites it off with the mandibulae (Meglitsch 1967). The occurrence of a high proportion of 'decapitated' fragments in the guts, which are as long as those with intact apices, suggests that 'standard' size portions are bitten off from the filaments several times.

Rhodochorton purpureum fragments have the capacity to survive passage through the guts of both animals. In freshly produced faecal pellets $R$. purpureum fragments were clearly discernible (Fig. $3 \mathrm{~A} \& 4 \mathrm{~A}$, arrows) and their viability was proved by their regeneration into long filaments when cultured in the laboratory (Fig. $3 \mathrm{~B} \& 4 \mathrm{~B}$ ). In the field, regenerating fragments were also observed. They could not be distinguished in the dense mat of interwoven rhizoids which constitutes the basis of the R. purpureum turf, but they were frequently observed on bare granite substrate where they appeared as small isolated tufts of erect filaments. The fragments from which these regenerating filaments arose were always embedded in sticky, detritus-rich envelopes, probably faecal pellets.

We confirmed the observation (Pearlmutter \& Vadas 1978) that the regenerative capacity of Rhodochorton purpureum fragments is very high. Unialgal, culturegrown plants started to regenerate within a few days (Table 1), and regeneration proceeded over a wide range of temperature and light conditions and even took place in total darkness (Table 1).

We suggest that the capacity to escape digestion by herbivores is an important mechanism for successful propagation in Rhodochorton purpureum. For this species, where propagation largely depends on frag- 

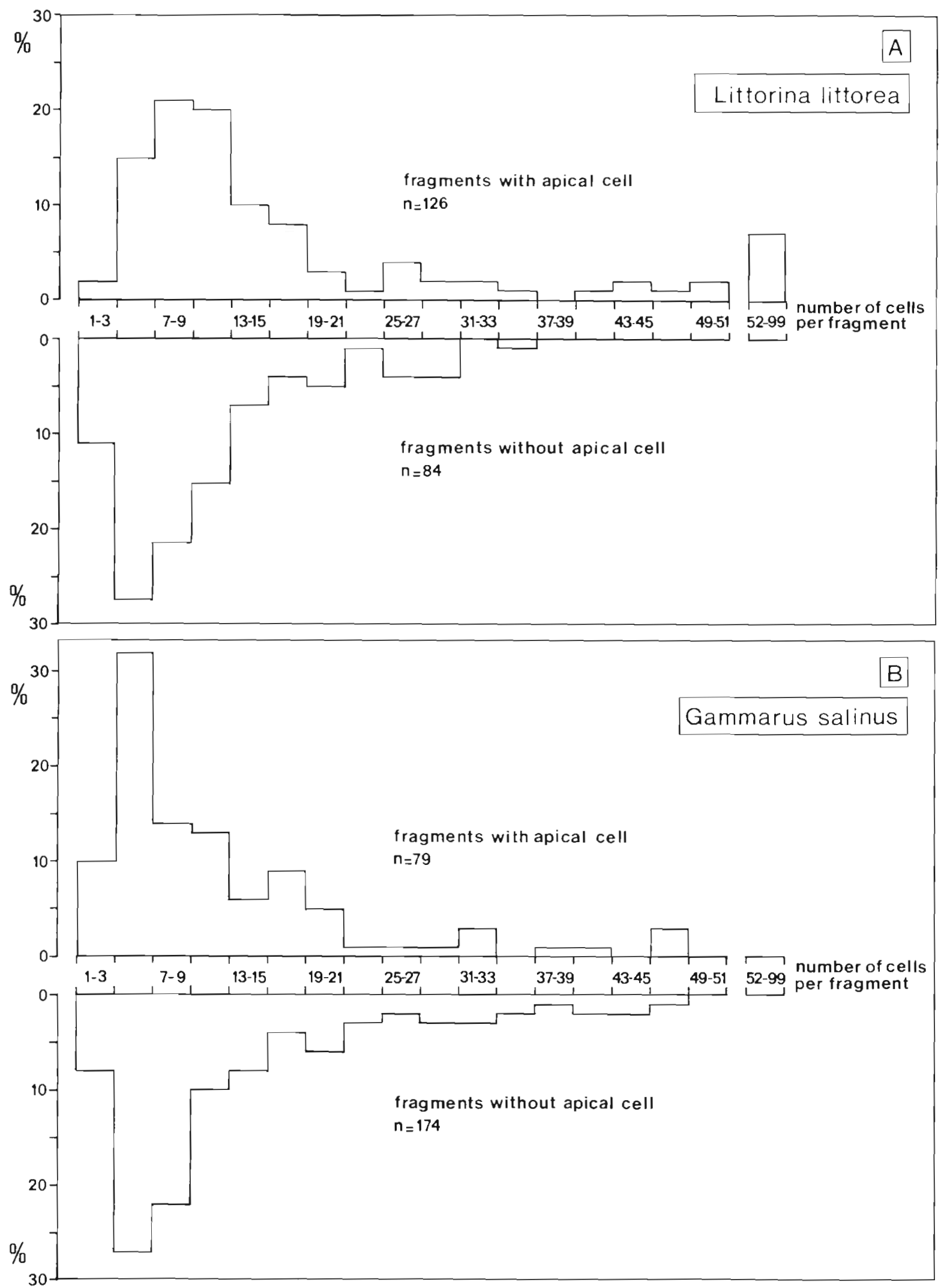

Fig. 2. Rhodochorton purpureum. Relative frequency of size classes of fragments (A) in the stomach of Littorina littorea and (B) in the guts of Gammarus salinus 

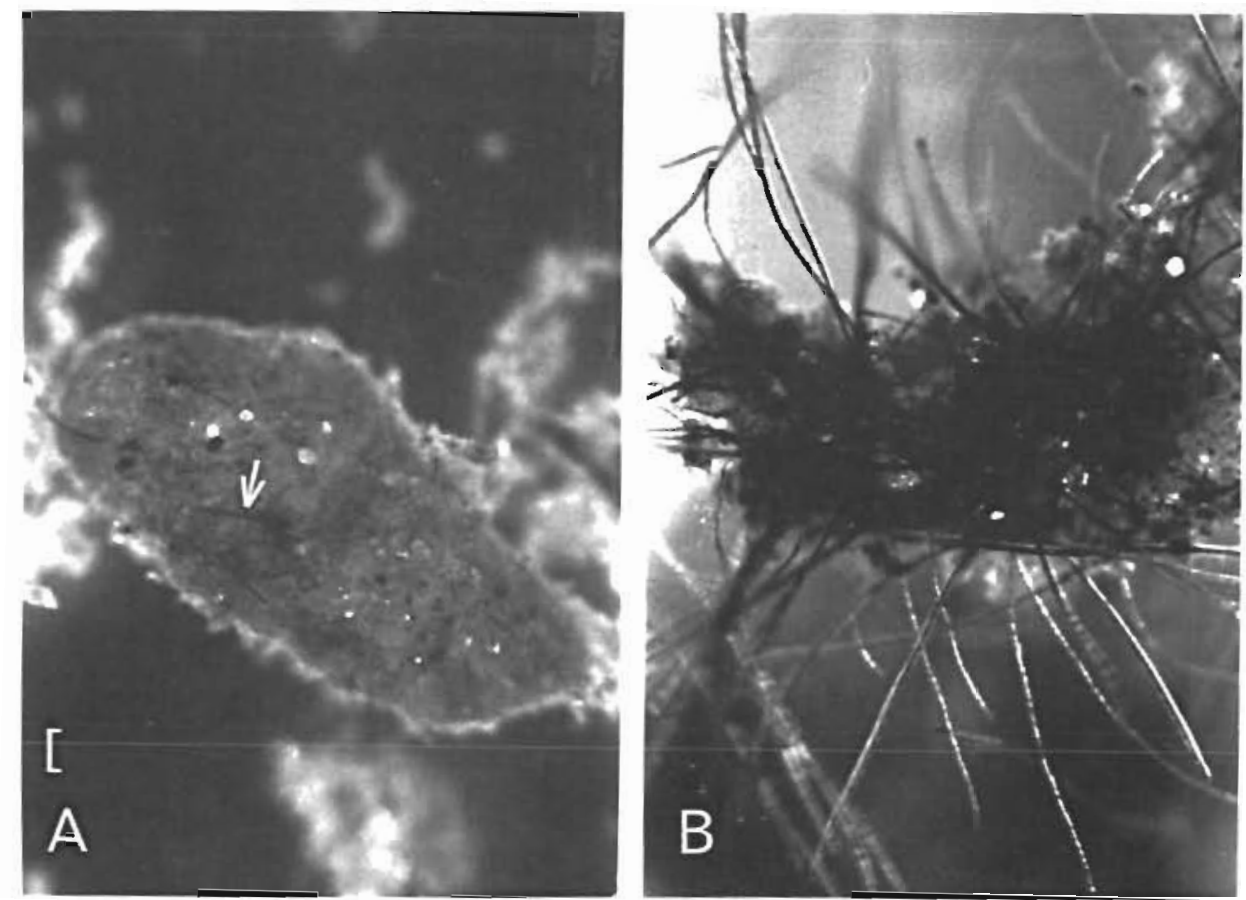

Fig. 3. Littorina Iittorea. Faecal pellet (A) just after production and (B) after 28 d. Note Rhodochorton purpureum fragments in new faecal pellet (A; arrow) and regenerating filaments $(B)$. Scale bar $=0.1 \mathrm{~mm}$
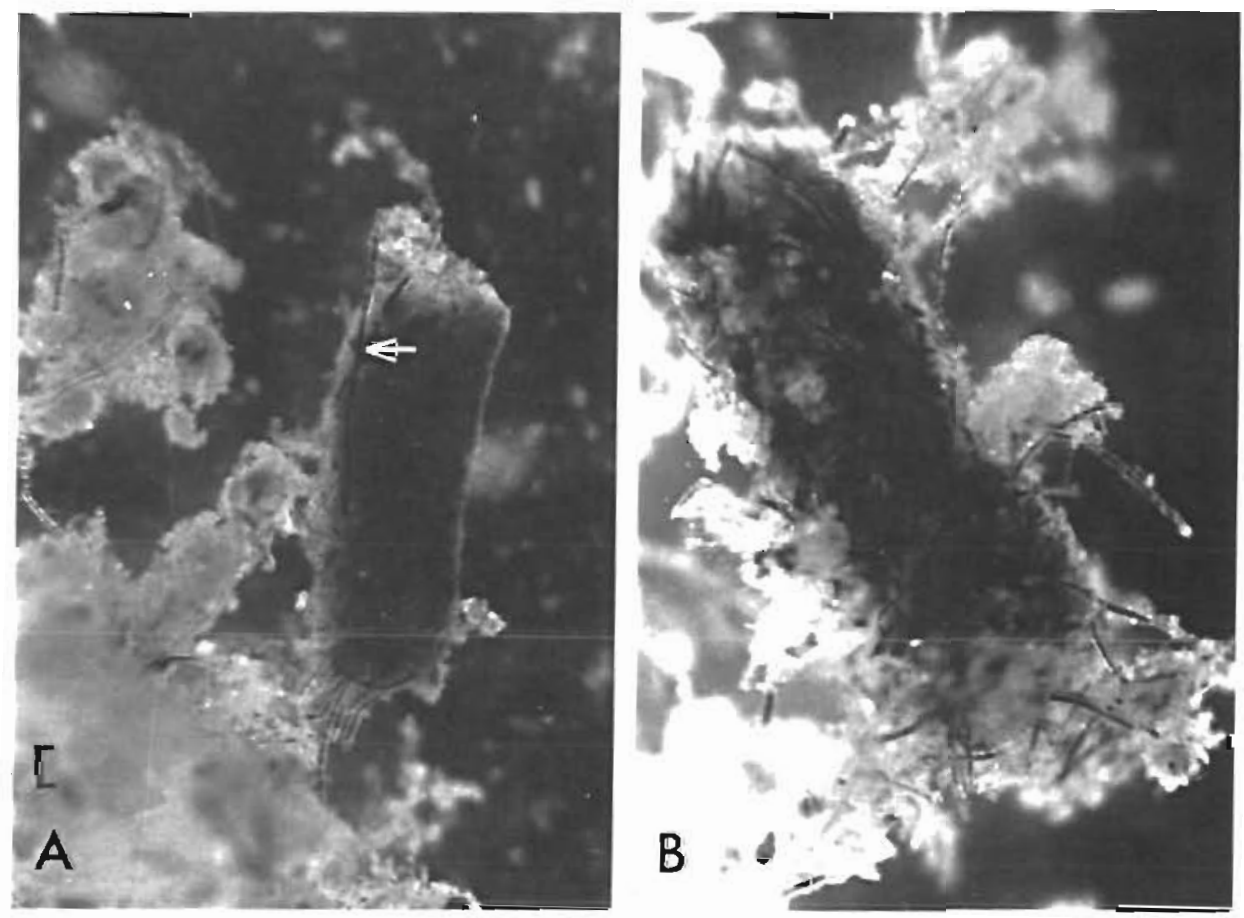

Fig. 4. Gammarus salinus. Faecal pellet (A) just after production and (B) after 28 d. Note Rhodochorton purpureum fragments in new faecal pellet ( $A$; arrow) and regenerating filaments $(B)$. Scale bar $=0.1 \mathrm{~mm}$ 
Table 1. Rhodochorton purpureum. Effects of temperature and light on the regeneration of fragments in uniagal cultures. Regeneration was measured as the number of fragments that had formed a rhizoid or an erect filament 3 and $12 \mathrm{~d}$ after fragmentation $(n \approx 500$ ). Effect of various temperature conditions was tested in $8 \mathrm{~h}$ days at a photon fluence rate of $40 \mu$ mol $\mathrm{m}^{-2} \mathrm{~s}^{-1}$; effect of various light conditions was tested at a temperature of $12^{\circ} \mathrm{C}$

\begin{tabular}{|c|c|c|c|c|c|c|}
\hline \multicolumn{3}{|c|}{ Effect of temperature } & \multicolumn{4}{|c|}{ Effect of light } \\
\hline \multirow{2}{*}{$\begin{array}{c}\text { Temperature } \\
\left({ }^{\circ} \mathrm{C}\right)\end{array}$} & \multicolumn{2}{|c|}{ Regenerating fragments $(\%)$} & \multirow{2}{*}{$\begin{array}{l}\text { Photon fluence rate } \\
\left.\text { (umol m } \mathrm{m}^{-2} \mathrm{~s}^{-1}\right)\end{array}$} & \multirow{2}{*}{$\begin{array}{l}\text { Daylength } \\
\text { (h) }\end{array}$} & \multicolumn{2}{|c|}{ Regenerating fragments $(\%)$} \\
\hline & After $3 \mathrm{~d}$ & After $12 d$ & & & After $3 d$ & After $12 \mathrm{~d}$ \\
\hline 4 & 3 & 9 & 0 & 0 & 5 & 56 \\
\hline 8 & 7 & 64 & 2.5 & 8 & 9 & 65 \\
\hline 12 & 5 & 71 & 5 & 8 & 5 & 71 \\
\hline 16 & 18 & 82 & 5 & 12 & 7 & 84 \\
\hline 18 & 23 & 87 & 5 & 16 & 9 & 80 \\
\hline 20 & 25 & 89 & 10 & 8 & 9 & 77 \\
\hline 24 & 25 & 87 & 20 & 8 & 6 & 85 \\
\hline \multirow[t]{2}{*}{26} & 6 & 10 (died later) & 40 & 8 & 7 & 79 \\
\hline & & & 80 & 8 & 5 & 81 \\
\hline
\end{tabular}

mentation, being eaten by an herbivore and being egested inside a faecal pellet will achieve several purposes. First, the herbivore will fragment the thallus, and this will be a far more effective means of fragmentation than physical or chemical damage. Secondly, egested fragments will be contained in a sticky envelope which will prevent their being washed off at high tide during the few days it takes to form an adhesive rhizoid. Thirdly, the fragments will be amply supplied with nutrients, which may promote their regeneration. Finally, herbivore movement will ensure some dispersal of the propagules.

We conclude that incomplete digestion by herbivores may be an important mechanism for vegetative propagation in filamentous benthic algae.

Acknowledgements. We thank. Mr. L. L. van Mulekom for his help with some of the experiments and Dr. E. D. de Ruyter van Steveninck for his comments on the manuscript.

\section{LITERATURE CITED}

Breeman, A. M., Bos, S., Essen, S. van, Mulekom, L. L. van (1984). Light-dark regimes in the intertidal zone and tetrasporangial periodicity in the red alga Rhodochorton purpureum. Helgoländer Meeresunters. 38: 365-387

Hawkins, S. J., Hartnoll, R. G. (1983). Grazing of intertidal algae by marine invertebrates. Oceanogr. mar. Biol. A. Rev, 21: 195-282

Jüch, P. J. W., Boekschoten, G. J. (1980). Trace fossils and grazing traces produced by Littorina and Lepidochitona, Dutch Wadden Sea. Geologie en Mijnbouw 59: 33-42

Knaggs, F. W. (1966). Rhodochorton purpureum (Lightf.) Rosenvinge. Observations on the relationship between morphology and environment 11. Nova Hedwigia 11: $337-349$

Knaggs, F. W. (1967). A review of the world distribution and the ecology of Rhodochorton purpureum (Lightf.) Rosenv. Nova Hedwigia 14: 549-570

Lubchenco, J., Gaines, S. D. (1981). A unified approach to marine plant-herbivore interactions. I. Populations and communities. Ann. Rev. Ecol. Syst. 12: 405-437

Meglitsch, P. A. (1967). Invertebrate zoology. Oxford University Press, Oxford

Ohta, M., Kurogi, M. (1979). On the life history of Rhodochorton purpureum (Lightf.) Rosenvinge from Hokkaido in culture. Jap. J. Phycol. 27: 161-167

Pearlmutter, N. L., Vadas, R. L. (1978). Regeneration of thallus fragments of Rhodochorton purpureum (Rhodophyceae, Nemalionales). Phycologia 17: 186-190

Santelices, B., Correa, J. (1985). Differential survival of macroalgae to digestion by intertidal herbivore molluscs. J. exp. mar. Biol. Ecol. 88: 183-191

Santelices, B., Correa, J., Avila, M. (1983). Benthic algal spores surviving digestion by sea urchins. J. exp. mar. Biol. Ecol. 70: 263-269

Stegenga, H. (1978). The life histories of Rhodochorton purpureum and Rhodochorton floridulum (Rhodophyta, Nemaliales) in culture. Br, phycol. J. 13: 279-289

Steneck, R. S., Watling, L. (1982). Feeding capabilities and limitation of herbivorous moliuscs: A functional group approach. Mar. Biol. 68: 299-319

Vadas, R. L. (1985). Herbivory. In: Littler, M. M., Littler, D. S. (ed.) Handbook of phycological methods. Ecological field methods: macroalgae. Cambridge University Press, Cambridge, p. 531-572

West, J. A. (1969). The life histories of Rhodochorton purpureum and $R$. tenue in culture. J. Phycol. 5: 12-21

West, J. A. (1972). Environmental regulation of reproduction in Rhodochorton purpureum. In: Abbott, I. A., Kurogi, M. (ed.) Contributions to the systematics of benthic marine algae of the North Pacific. Jap. Soc. Phycol., Kobe, p. $213-230$

Accepted for printing on November 14, 1986 